\title{
Hipertoniczne roztwory soli w terapii chorób dróg oddechowych
}

\section{Hypertonic saline solution in the treatment of respiratory diseases}

\author{
Andrzej Emeryk ${ }^{1}$, Justyna Emeryk-Maksymiuk ${ }^{2}$, Kamil Janeczek ${ }^{1}$, Arkadiusz Jędrzejewski ${ }^{3}$ \\ ${ }^{1}$ Klinika Chorób Płuc i Reumatologii Dziecięcej, Uniwersytet Medyczny w Lublinie \\ Kierownik Kliniki: prof. dr hab. n. med. Andrzej Emeryk \\ ${ }^{2}$ Katedra i Zakład Pielęgniarstwa Internistycznego, Uniwersytet Medyczny w Lublinie \\ Kierownik: dr hab. n. med. Agnieszka Zwolak \\ ${ }^{3}$ Katedra i Zakład Pielęgniarstwa Pediatrycznego, Uniwersytet Medyczny w Lublinie \\ Kierownik: dr hab. n. med. Danuta Zarzycka
}

\section{Streszczenie:}

Przedstawiono dowody skuteczności hipertonicznych roztworów soli w przeziębieniu, alergicznym nieżycie nosa, nieżycie błony śluzowej nosa i zatok przynosowych, zapaleniu oskrzelików, mukowiscydozie i rozstrzeniach oskrzeli u dzieci i dorosłych w oparciu o przeglądy systematyczne z metaanalizą i badania publikowane w czasopismach posiadających impact factor.

\section{Abstract:}

Evidence of the efficacy of hypertonic saline solutions in the common cold, allergic rhinitis, rhinosinusitis, bronchiolitis, cystic fibrosis, and bronchiectasis in children and adults is presented based on systematic reviews with meta-analysis and studies published in journals with impact factor.

Słowa kluczowe: hipertoniczny roztwór soli, przeziębienie, alergiczny nieżyt nosa, nieżyt błony śluzowej nosa i zatok przynosowych, zapalenie oskrzelików, mukowiscydoza, rozstrzenia oskrzeli, nebulizacja

Key words: hypertonic saline solution, common cold, allergic rhinitis, rhinosinusitis, bronchiolitis, cystic fibrosis, bronchiectasis, nebulization

\section{Wstęp}

Roztwory chlorku sodu lub roztwory różnych soli występujących $w$ wodzie morskiej są używane w medycynie od kilku tysięcy lat, a jeden z pierwszych naukowych opisów zastosowania roztworów soli $\mathrm{w}$ chorobach dróg oddechowych powstał przed blisko 120 laty [1, 2]. Wyróżnia się wodny izotoniczny roztwór soli (IRS), zawierający roztwór chlorku sodu $0,9 \%$ (potocznie nazywany sola fizjologiczna), oraz hipertoniczne roztwory soli (HRS). Te ostatnie sa stosowane w różnych stężeniach: 1,0-10,0\%, najczęściej w zakresie $2,0-4,5 \%$ [3]. HRS mają szerokie zastosowanie w ostrych i przewleklych chorobach zapalno- -infekcyjnych górnych i dolnych dróg oddechowych, występują w różnych formulacjach. Dostępne są jako:

- roztwór do irygacji jam nosa (ampułki, butelki, różne urządzenia pomocnicze)

- roztwór donosowy z dozownika ciśnieniowego

- roztwór donosowy aplikowany z butelki z atomizerem

- roztwór do nebulizacji (ampułki).

Te ostatnie ze względu na swoje właściwości fizykochemiczne nadają się do nebulizatorów pneumatycznych, ultradźwiękowych klasycznych oraz siateczkowych [4]. 
HRS podawane w dowolnej formulacji donosowo rozrzedzają zalegającą wydzielinę, ułatwiając oczyszczanie jam nosa, ale też zmniejszają obrzęk i nawilżają błonę śluzową nosa [5]. W przypadku płukania nosa czy też nawilżania jam nosowych bardzo ważnym elementem jest właściwa technika wykonywania takich zabiegów [6, 7].

HRS podawane dooskrzelowo (nebulizacja) działają jako leki mukoaktywne (grupa leków wykrztuśnych) [8]. Mechanizm ich działania opiera się na pobudzeniu sekrecji gruczołowej, zwiększeniu zawartości wody w wydzielinie oskrzelowej oraz zmniejszeniu lepkości wydzieliny zalegającej w drogach oddechowych [9].

\section{Cel pracy}

Celem pracy była próba przedstawienia i oszacowania dowodów skuteczności oraz bezpieczeństwa stosowania HRS w terapii chorób dróg oddechowych u ludzi.

\section{Material i metody}

Dokonano przeglądu publikacji z bazy PubMed z okresu 2000-2020, wpisując słowa hypertonic saline solution or hypertonic saline irrigation or hypertonic saline inhalation. Wybrano publikacje dotyczące przeziębienia, alergicznego nieżytu nosa (ANN), zapalenia błony śluzowej nosa i zatok przynosowych, zapalenia oskrzelików, mukowiscydozy oraz rozstrzeni oskrzeli niezwiązanych $z$ mukowiscydozą. Analizowano jedynie publikacje zawierające przeglądy systematyczne z metaanalizą oraz publikacje badań randomizowanych i kontrolowanych $\mathrm{z}$ czasopism posiadających impact factor. Przedstawiono też aktualne stanowiska i/lub rekomendacje międzynarodowe $\mathrm{i} / \mathrm{lub}$ krajowe dotyczące omawianego problemu.

\section{Przeziębienie}

Przeziębienie to zespół objawów związanych z zapaleniem błony śluzowej nosa, gardła i zatok przynosowych, spowodowany zakażeniem wirusowym [10]. W chorobie zastosowanie mają zarówno IRS, jak i HRS. Dostępny jest jeden przegląd systematyczny z metaanalizą, w większości z badań z IRS (544 dzieci w trzech badaniach oraz 205 dorosłych w dwóch badaniach) [11]. Porównywano w nim irygację nosową z IRS do rutynowego postępowania lub użycia innych aerozoli donosowych. Autorzy tego opracowania wykazali, iż irygacja nosa IRS przynosi korzyści w łagodzeniu objawów (głównie zatkania nosa) ostrych zakażeń wirusowych górnych dróg oddechowych przy dobrej tolerancji takiego postępowania, co znalazło odzwierciedlenie w późniejszej publikacji van Driel i wsp. [12]. W 2019 r. opublikowano ciekawe, choć jedynie pilotowe badanie dotyczące nosowej irygacji (i płukania gardła) HRS u dorosłych z typowymi objawami przeziębienia [13]. Okazało się, że w grupie poddanej interwencji HRS w stosunku do grupy kontrolnej:

- czas trwania objawów był krótszy o 1,9 dnia $(\mathrm{p}=0,01)$

- zużycie leków OTC było mniejsze o 36\% $(p=0,004)$

- spadła transmisja wirusów w kontaktach domowych o $35 \%(p=0,006)$

- wydalanie wirusów było mniejsze $(p=0,04)$.

Ten efekt można tlumaczyć działaniem przeciwwirusowym kwasu podchlorawego (HOCl) wytwarzanego w komórkach nabłonka $z$ jonów chlorkowych [14]. Ostatnio ci sami autorzy wykazali pewną skuteczność kliniczną opisanego powyżej postępowania u siedmiu chorych eksperymentalnie zakażonych różnymi typami koronawirusów (HCoV-229E, HCoV-NL63, HCoV-HKU1), co może budzić nadzieję na skuteczność takiej terapii u chorych na COVID-19 [14]. Podsumowując dotychczasowe publikacje, należy wskazać, iż potrzebne są dalsze badania, randomizowane, kontrolowane, podwójnie zaślepione, także z udziałem grupy dziecięcej, do zweryfikowania skuteczności i bezpieczeństwa HRS w leczeniu przeziębień.

\section{Alergiczny nieżyt nosa}

Donosowa aplikacja HRS jest od lat dodatkową opcją terapeutyczną (terapią dodaną) u pacjentów chorych na alergiczny nieżyt nosa sezonowy (ANNs) i/lub alergiczny nieżyt nosa całoroczny (ANNc), pomimo ciągle ograniczonych dowodów skuteczności takiego postępowania. Najnowszy przegląd systematyczny z metaanalizą opublikowano w 2018 r. Zawierał on dane z 14 badań, w tym siedmiu u dzieci (499 dzieci) oraz siedmiu u dorosłych (248 osób) [15]. Dotyczył zarówno IRS, jak i HRS, a podawane objętości roztworów nie były jednolite w poszczególnych pracach. Autorzy tego opracowania stwierdzili, że:

- irygacja IRS lub HRS (w tym woda morska) zmniejsza nasilenie objawów ANN w porównaniu z grupą, w której nie stosowano tego typu postępowania

- korzystny efekt irygacji dotyczył zarówno dorosłych, jak i dzieci

- pacjenci nie zgłaszali istotnych działań niepożądanych 
- brak jest danych dotyczących jakichkolwiek wyników takiej terapii przez okres dłuższy niż 3 miesiące

- ogólna jakość dostępnych danych naukowych była niska lub bardzo niska, a badania dotyczyły na ogół niewielkich populacji i wykorzystywały różne zmienne końcowe (wskaźniki) oceniające ciężkość choroby z niejasną walidacją.

Przegląd ten nie obejmował bezpośrednich porównań rodzajów soli, tzn. IRS vs HRS, dużych objętości vs małe, różnych sposobów aplikacji donosowych. Autorzy tej metaanalizy wskazują, iż irygacje solami mogą stanowić tanią, bezpieczną i akceptowalną przez chorych alternatywę dla glikokortykosteroidów donosowych i leków przeciwhistaminowych. Jednak potrzebne są dalsze badania o wysokiej jakości w dobrze zdefiniowanych grupach chorych. Podobne wnioski płyną z metaanalizy Li i wsp. dotyczącej jedynie populacji pediatrycznej, przy czym większą efektywność kliniczną miały preparaty HRS vs IRS [16].

Znamy kilka badań, w których próbowano wyjaśnić mechanizmy skuteczności HRS w ANN. Między innymi stwierdzono, że HRS w porównaniu $z$ IRS znacząco zmniejsza liczbę neutrofilów oraz eozynofilów w błonie śluzowej nosa u chorych na ANN [17]. Usuwa zalegającą wydzielinę, nawilża śluzówkę, jak również powoduje łagodzenie objawów nosowych ANN, dzięki czemu zmniejsza zużycie innych leków. Wykazano także przyspieszenie oczyszczania śluzowo-rzęskowego, co z kolei zmniejsza czas kontaktu alergenu z błoną śluzową. Szybkie usuwanie białek alergenowych zabezpiecza przed tworzeniem się procesu zapalnego, a zatem taka terapia wywiera ponadto działanie prewencyjne [18]. Roztwory HRS są szczególnie skuteczne w szczycie sezonu pylenia u chorych naANNs [19]. Jednocześnie preparaty te są dobrze tolerowane przez dzieci i dorosłych chorych na różne postacie ANN. To tanie i powszechnie dostępne leczenie powinno być szerzej rozpropagowane wśród dzieci i dorosłych chorych na ANN, na co wskazał przed kilku laty zespół ekspertów Polskiego Towarzystwa Alergologicznego [20].

Zapalenie błony śluzowej nosa i zatok przynosowych Preparaty HRS od wielu lat znajdują zastosowanie zarówno w terapii ostrego, jak i przewlekłego nieżytu błony śluzowej nosa i zatok przynosowych. Wskazują na to eksperci w dokumencie EPOS 2012 (Europejskie wytyczne na temat zapalenia zatok przynosowych i polipów nosa 2012) [21]. Siłę rekomendacji oceniono na I A (rekomendacja najsilniejsza, oparta na wysoce wiarygodnych badaniach klinicznych). Podobne zalecenia znalazły się w wydanym 2 lata później dokumencie International Consensus (ICON) on Chronic Rhinosinusitis [22].

W 2016 r. został opublikowany przegląd systematyczny z metaanalizą badań w przewlekłym nieżycie błony śluzowej nosa i zatok przynosowych. Zakwalifikowano do niej jedynie dwa badania obejmujące 116 dorosłych [23]. Jednakże różniły się one bardzo pod względem uwzględnionych populacji, interwencji i badanych zmiennych, dlatego trudno jest wyciągnąć silne wnioski, które mogłyby mieć zastosowanie w praktyce klinicznej. Niemniej wskazano, że:

- nebulizacja donosowa małą objętością (5 ml) IRS nie przynosi korzyści w porównaniu z glikokortykosteroidami donosowymi

- istnieją pewne korzyści z codziennej irygacji dużą objętością (150 ml) HRS vs placebo, ale jakość danych naukowych po 3 miesiącach leczenia jest niska, a po 6 miesiącach bardzo niska.

W kolejnej metaanalizie, sprzed 2 lat, wykazano, że irygacje HRS zmniejszają objawy zapalenia błony śluzowej nosa i zatok przynosowych efektywniej niż IRS, niosąc jednak ryzyko łagodnych działań niepożądanych vs IRS [24]. Ponadto płukanie jam nosa jest ważnym elementem postępowania $\mathrm{w}$ okresie rekonwalescencji po zabiegach chirurgicznych w obrębie nosa i zatok przynosowych [25]. Pomaga ono usunąć skrzepy krwi, zalegającą w jamach nosa gęstą wydzielinę śluzową oraz zmniejszyć obrzęki błony śluzowej w okresie pooperacyjnym. $\mathrm{W}$ sumie ułatwia to gojenie się operowanej okolicy, a także umożliwia penetrację innych leków aplikowanych miejscowo. Potrzebne są jednak dalsze badania nad doborem właściwego stężenia HRS [26]. Wiadomo już, że ogrzanie roztworu soli nie przynosi lepszych rezultatów niż płukanie jam nosa roztworem o temperaturze pokojowej [27].

\section{Mukowiscydoza}

Podstawą do stosowania HRS w stężeniach 3-14\% w mukowiscydozie było wykazanie poprawy oczyszczania tchawiczo-oskrzelowego u chorych z przewlekłymi stanami zapalnymi oskrzeli. Efekt ten zachodzi w wyniku indukowania przez HRS przepływu cieczy z nabłonka dróg oddechowych do śluzu, zmieniając w ten sposób jego właściwości reologiczne, dzięki czemu jest łatwiej usuwany przez rzęski [28]. Badania wykazały, że:

- długotrwałe stosowanie HRS w nebulizacji poprawia czynność płuc u pacjentów z mukowiscydozą; 
jednak jest to efekt słabszy niż nebulizacja deoksyrybonukleazy (rhDNaza)

- korzystnym efektem inhalacji HRS 7\% jest istotne zwiększenie efektywności antybiotykoterapii inhalacyjnej [29-31].

Podsumowanie najważniejszych efektów terapii HRS u chorych na mukowiscydozę zawiera najnowszy przegląd systematyczny z metaanalizą, opublikowany w 2018 r. Wskazuje on, że:

- HRS w nebulizacji $(3-7 \%, 10 \mathrm{ml}$ dwa razy dziennie) stosowany przez 4 tygodnie u dzieci powyżej 12. r.ż. i dorosłych powoduje przyrost wartości $\mathrm{FEV}_{1}$ (nasilona objętość wydechowa pierwszosekundowa) o 3,44\% w stosunku do wartości wyjściowej (dowód bardzo niskiej jakości pochodzący $\mathrm{z}$ trzech badań, $\mathrm{n}=225$ )

- $\quad$ po 48 tygodniach terapii efekt ten był nieco gorszy - wzrost $\mathrm{FEV}_{1}$ jedynie o 2,31\% (dowód niskiej jakości pochodzący z jednego badania, $n=134$ )

- w jednym badaniu (162 osoby dorosłe) stwierdzono istotną redukcję zaostrzeń choroby wymagających antybiotykoterapii w grupie HRS (dowody niskiej jakości)

- w jednym badaniu u dzieci (243 dzieci, średni wiek: 2 lata) nie wykazano efektu terapeutycznego lub był on znacznie mniejszy niż nebulizacja rhDNazy (dowody niskiej jakości)

- HRS wydaje się skutecznym uzupełnieniem fizjoterapii podczas zaostrzeń płucnych tej choroby u dorosłych (dowody bardzo niskiej jakości) [32].

Terapia HRS jest zalecana w międzynarodowych i krajowych rekomendacjach, stanowiąc cenne uzupełnienie innych metod farmakoterapii mukowiscydozy w różnych fazach choroby [33-35].

\section{Rozstrzenia oskrzeli niezwiązane z mukowiscydozą}

Kolejnym wskazaniem do stosowania HRS są rozstrzenia oskrzeli niezwiązane $z$ mukowiscydozą. W tych schorzeniach wykazano, że inhalacje z HRS lub IRS mają podobne efekty, biorąc pod uwagę wpływ na zaostrzenia choroby, jakość życia chorych, kolonizację plwociny i parametry spirometryczne w okresie co najmniej 12-miesięcznej terapii [36]. Najnowszy przegląd systematyczny z metaanalizą wskazuje, że:

- terapia HRS (3-7\%) jest efektywniejsza w usuwaniu wydzieliny oskrzelowej vs techniki aktywnego cyklu oddechowego (ACBT) vs IRS (po 3 miesiącach terapii, ale nie po 12 miesiącach)
- wielomiesięczna terapia HRS w niewielkim stopniu poprawia jakość życia chorych vs IRS i w podobnym stopniu do IRS po 12 miesiącach leczenia

- HRS zmniejsza roczny wskaźnik zaostrzeń vs placebo po 3 miesiącach terapii $(2,14$ vs 4,85$)$, brak jest tego efektu po 12 miesiącach nebulizacji

- HRS łączy się z mniejszym rocznym wskaźnikiem hospitalizacji vs IRS (IRS $=4,85$ vs HRS $=2,14$ ) po 3 miesiącach terapii, ale nie po 12 miesiącach [37].

Na bezpieczeństwo terapii HRS w tej grupie chorych zwraca uwagę przewodnik Brytyjskiego Towarzystwa Chorób Klatki Piersiowej (BTS, British Thoracic Society) z 2010 r. [38]. Jego autorzy wskazują, iż:

- można rozważyć zastosowanie nebulizacji z HRS przed drenażem dróg oddechowych w celu zwiększenia ilości plwociny, zmniejszenia jej lepkości i ułatwienia odkrztuszania

- w przypadku nebulizacji HRS po raz pierwszy u danego chorego należy zmierzyć wartość FEV lub PEF przed leczeniem i 5 min po leczeniu, aby ocenić możliwość wystąpienia skurczu oskrzeli

- u osób z nadreaktywnością oskrzeli poddawanych nebulizacji z HRS należy wstępnie zastosować lek rozszerzający oskrzela (salbutamol).

U osób nietolerujących HRS dodanie kwasu hialuronowego może tę tolerancję poprawić [39].

\section{Zapalenie oskrzelików u dzieci}

HRS zmieniają właściwości zalegającej w oskrzelikach wydzieliny, co poprawia oczyszczanie śluzowo-rzęskowe, a dzięki temu drożność dolnych dróg oddechowych u dzieci chorych na zapalenie oskrzelików [40-42]. Dlatego też niektóre rekomendacje, w tym American Academy of Pediatrics oraz polskie rekomendacje postępowania w pozaszpitalnych zakażeniach układu oddechowego, wskazują na korzyści z zastosowania HRS w nebulizacji w tej chorobie, jednocześnie zaznaczając, że doniesienia dotyczące efektów takiego postępowania są niejednoznaczne $[43,44]$.

W 2014 r. Chen i wsp. opublikowali przegląd systematyczny z metaanalizą 11 badań obejmujących łącznie 1070 niemowląt. Autorzy wykazali, że nebulizacja HRS wiązała się z krótszym czasem pobytu w szpitalu oraz mniejszym ryzykiem hospitalizacji w przypadku pacjentów leczonych ambulatoryjnie (odpowiednio $\mathrm{p}<0,001 ; \mathrm{p}=0,02$ ). Nie obserwowano istotnych różnic pomiędzy porównywanymi 
grupami (HRS vs IRS) w zakresie częstości readmisji $(\mathrm{p}=0,74)[45]$.

Kolejna metaanaliza autorstwa Zhang i wsp., która objęła 24 badania kliniczne (3209 dzieci), wykazała, że stosowanie HRS u dzieci z zapaleniem oskrzelików w warunkach ambulatoryjnych wiązało się ze zmniejszeniem ryzyka hospitalizacji o $20 \%$. Nie stwierdzono istotnych działań niepożądanych związanych z nebulizacją HRS vs IRS. Jakość dowodów autorzy oceniają jako średnią ze względu na heterogeniczność wyników badań włączonych do metaanalizy [46]. W 2017 r. autorzy ponownie dokonali przeglądu baz danych i zaktualizowali swoją metaanalizę o nowe badania kliniczne, stwierdzając, że:

- niemowlęta otrzymujące HRS w nebulizacji w warunkach szpitalnych miały statystycznie istotnie krótszy średni czas pobytu w szpitalu w porównaniu $\mathrm{z}$ dziećmi nebulizowanymi IRS (MD -0,41 dnia; 95\% CI od -0,75 do -0,07; p =0,02) (jakość dowodów niska)

- u dzieci otrzymujących HRS w warunkach szpitalnego oddziału ratunkowego występowało o $14 \%$ mniejsze ryzyko hospitalizacji niż u dzieci otrzymujących IRS $(\mathrm{RR}=0,86 ; 95 \%$ CI 0,76 - 0,98; $\mathrm{p}=0,02$ ) (jakość dowodów umiarkowana) [47].

Bezpieczeństwo HRS zostało ocenione w 24 badaniach, z czego w 13 badaniach nie odnotowano żadnych działań niepożądanych, a w 11 badaniach zgłoszono co najmniej jedno zdarzenie niepożądane, z których większość była łagodna i ustępowała samoistnie. Najczęściej obserwowano nasilenie kaszlu [47].

W kolejnej metaanalizie, z 2018 r., Zhang i wsp. zaznaczają, że redukcja ryzyka hospitalizacji dotyczy tylko dzieci, u których HRS w nebulizacji podawano łącznie z wziewnymi lekami bronchodylatacyjnymi [48]. W tym samym roku ukazała się praca, w której wykorzystano metodę analizy sekwencyjnej (TSA, Trial Sequential Analysis) w celu oceny, czy dostępne metaanalizy są wystarczające do wyciągnięcia jednoznacznych wniosków na temat skuteczności HRS w terapii zapalenia oskrzelików u dzieci. Zgodnie z TSA metaanalizy wykazujące wpływ nebulizacji HRS na zmniejszenie ryzyka hospitalizacji oraz skrócenie czasu hospitalizacji mogą dostarczać wyników fałszywie dodatnich [49].

W 2019 r. opublikowano przegląd systematyczny rekomendacji dotyczących diagnostyki oraz leczenia zapalenia oskrzelików w różnych krajach. Osiem rekomendacji zaleca rutynowe stosowanie HRS, podczas gdy pozostałe siedem nie zaleca tego typu terapii (m.in. wytyczne szwedzkie i brytyjskie) [50]. Zgodnie z polskimi wytycznymi nebulizacja roztworem chlorku sodu $3 \%$ nie jest rekomendowana do rutynowego stosowania u dzieci z zapaleniem oskrzelików leczonych ambulatoryjnie, można ją rozważyć w przypadku dzieci leczonych w warunkach szpitalnych (w połączeniu z lekiem bronchodylatacyjnym) [44]. Podobne stanowisko znajdujemy w wytycznych American Academy of Pediatrics [43].

Podsumowując, można stwierdzić, że aktualnie dostępne badania charakteryzują się dużą niejednorodnością prezentowanych wyników i tym samym brak jednoznacznych dowodów na rutynowe stosowanie HRS w leczeniu zapalenia oskrzelików u dzieci, zarówno w warunkach ambulatoryjnych, jak i szpitalnych.

\section{Inne choroby dróg oddechowych}

Kwestia przydatności HRS w terapii innych przewlekłych chorób dróg oddechowych, takich jak zespół dyskinetycznych rzęsek czy przewlekła obturacyjna choroba płuc (POChP), jest wysoce kontrowersyjna [51-54]. W wybranych przypadkach zespołu dyskinetycznych rzęsek terapia HRS może przynieść korzyści kliniczne [51]. W przypadku POChP brak jest takiego zalecenia $\mathrm{w}$ aktualnym dokumencie GOLD (Global Initiative for Chronic Obstructive Lung Disease) z 2020 r. [55].

\section{Podsumowanie}

Donosowe lub dooskrzelowe stosowanie HRS jest uznanym postępowaniem terapeutycznym w niektórych ostrych i przewlekłych schorzeniach górnych i dolnych dróg oddechowych przebiegających $z$ zaleganiem wydzieliny $w$ jamach nosa lub w tchawicy i oskrzelach. Jednakże jakość dowodów skuteczności aplikacji HRS jest na ogół niska, przede wszystkim ze względu na bardzo duże różnice metodologiczne między poszczególnymi badaniami (tab. 1). Dotyczą one m.in. różnorodnych stężeń HRS, zastosowanych objętości (dawek), sposobów dawkowania i czasu trwania terapii. Preparaty HRS są na ogół dobrze tolerowane przez chorych, zwłaszcza w niższych stężeniach. Należy zachować szczególną ostrożność przy ich nebulizowaniu u dzieci i dorosłych $z$ cechami nadreaktywności oskrzeli, np. u chorych na astmę (w tym astmę wczesnodziecięcą) czy POChP. W tabeli 1 zestawiono aktualne wskazania do stosowania HRS wraz z jakością dowodów skuteczności i siłą zaleceń dla takiego postępowania. 
Tabela 1. Aktualne możliwości zastosowania HRS w różnych formulacjach, jakość dowodów dotyczacych skuteczności i siła zaleceń do stosowania (opracowanie własne).

\begin{tabular}{|c|c|c|c|c|}
\hline Wskazania & $\begin{array}{l}\text { Stężenie } \\
(w \%)\end{array}$ & Postać farmaceutyczna & $\begin{array}{l}\text { Jakośí dowodów } \\
\text { skuteczności }\end{array}$ & $\begin{array}{c}\text { Siła } \\
\text { zaleceń }\end{array}$ \\
\hline Przeziębienie & $2,2-4,5$ & $\begin{array}{l}\text { roztwór do irygacji jam nosa z ampułki/butelki, roztwór donosowy } \\
\text { z dozownika ciśnieniowego lub z butelki z atomizerem }\end{array}$ & niska lub bardzo niska & słaba \\
\hline $\begin{array}{l}\text { Alergiczny nieżyt nosa } \\
\text { (wszystkie postacie) }\end{array}$ & $2,2-3,0$ & $\begin{array}{l}\text { roztwór do irygacji jam nosa z ampułki/butelki, roztwór donosowy } \\
\text { z dozownika ciśnieniowego lub z butelki z atomizerem }\end{array}$ & niska lub bardzo niska & silna \\
\hline $\begin{array}{l}\text { Zapalenie błony } \\
\text { śluzowej nosa i zatok } \\
\text { przynosowych }\end{array}$ & $1,8-3,0$ & $\begin{array}{l}\text { roztwór do irygacji jam nosa (ampułki, butelki), roztwór donosowy } \\
\text { z dozownika ciśnieniowego lub z butelki z atomizerem, roztwór do } \\
\text { nebulizacji }\end{array}$ & niska & silna \\
\hline Mukowiscydoza & $3,0-7,0$ & roztwór do nebulizacji & niska & silna \\
\hline Rozstrzenia oskrzeli & $3,0-7,0$ & roztwór do nebulizacji & umiarkowana & silna \\
\hline Zapalenie oskrzelików & $3,0-5,0$ & roztwór do nebulizacji & niska lub umiarkowana & wątpliwa \\
\hline
\end{tabular}

\section{Piśmiennictwo}

1. https://en.wikipedia.org/wiki/Nasal_irrigation (Access: 28.07.2020).

2. Wingrave $W$. The nature of discharges and douches. Lancet. 1902; 159: 1373-5.

3. Kassel JC, King D, Spurling GK et al. Saline nasal irrigation for acute upper respiratory tract infections. Cochrane Database Syst Rev. 2010; 3: CD006821.

4. Emeryk A, Pirożyński M. Nebulizacja: czym, jak, dla kogo, kiedy? Polski Konsensus Nebulizacyjny. Medycyna Praktyczna-Pneumonologia. 2013; 1; wydanie specjalne: 2-8.

5. Rabago D, Zgierska A. Saline Nasal Irrigation for Upper Respiratory Conditions. Am Fam Physician. 2009; 80(10): 1117-9.

6. Rapiejko P, Wojdas A, Ratajczak J et al. Techniques of intranasal drug use. Pol Mer Lek. 2005; 19(111): 400-2.

7. Rapiejko P, Lipiec A. Ptukanie czy nawilżanie? Alergoprofil. 2011; 7(1): 5-9.

8. Balsamo R, Lanata L, Egan CG. Mucoactive drugs. Eur Respir Rev. 2010; 19: 127-33.

9. Linssen RSN, Ma J, Bem RA et al. Rational use of mucoactive medications to treat pediatric airway disease. Paed Respir Rev. 2020. https://doi.org/10.1016/j.prrv.2020.06.007 (in press).

10. Kirkpatrick GL. The common cold. Prim Care. 1996; 23(4): 657-75.

11. King D, Mitchell B, Williams ChP et al. Saline nasal irrigation for acute upper respiratory tract infections. Cochrane Database Syst Rev. 2015; 4: CD006821.

12. van Driel ML, Scheire $S$, Deckx $L$ et al. What treatments are effective for common cold in adults and children? BMJ. 2018; 363: $k 3786$

13. Ramalingam S, Graham C, Dove $J$ et al. A pilot, open labelled, randomised controlled trial of hypertonic saline nasal irrigation and gargling for the common cold. Sci Rep. 2019; 9: 1015.

14. Ramalingam S, Graham C, Dove J et al. Hypertonic saline nasal irrigation and gargling should be considered as a treatment option for COVID-19. J Glob Health. 2020; 10(1): 010332.

15. Head K, Snidvongs $K$, Glew $S$ et al. Saline irrigation for allergic rhinitis. Cochrane Database Syst Rev. 2018; 6: CD012597.

16. Li CL, Lin HC, Lin CY et al. Effectiveness of Hypertonic Saline Nasal Irrigation for Alleviating Allergic Rhinitis in Children: A Systematic Review and Meta-Analysis. J Clin Med. 2019; 8(1): 64.

17. Malizia V, Fasola S, Ferrante G et al. Efficacy of Buffered Hypertonic Saline Nasal Irrigation for Nasal Symptoms in Children with Seasonal Allergic Rhinitis: A Randomized Controlled Trial. Int Arch Allergy Immunol. 2017; 174: 97-103.

18. Di Berardino F, Zanetti D, D'Amato G. Nasal rinsing with an atomized spray improves mucociliary clearance and clinical symptoms during peak grass pollen season. Am J Rhinol Allergy. 2017; 31: 40-3.

19. Rapiejko P, Jurkiewicz D. Wpływ stosowania roztworu izotonicznego wody morskiej (Marimer) na objawy chorobowe oraz stan błony śluzowej nosa u chorych z uczuleniem na alergeny pytku roślin. Alergoprofil. 2007; 3: 29-35.

20. Samoliński B, Arcimowicz M (ed). Polskie Standardy Leczenia Nieżytów Nosa (PoSLeNN). Stanowisko Panelu Ekspertów Polskiego Towarzystwa Alergologicznego. Alerg Pol. 2013; numer specjalny S1: 17-167.

21. Fokkens WJ, Lund VJ, Mullol J. European position paper on rhinosinusitis and nasal polyps 2012. Rhinol Suppl. 2012; 23: 1-298

22. Bachert $C$, Pawankar R, Zhang L et al. ICON: chronic rhinosinusitis. World Allergy Organ J. 2014; 7: 25. 
23. Chon LY, Head $K$, Hopkins $C$ et al. Saline irrigation for chronic rhinosinusitis. Cochrane Database Syst Rev. 2016; 4: CD011995.

24. Kanjanawasee D, Seresirikachorn K, Chitsuthipakorn $W$ et al. Hypertonic saline versus isotonic saline nasal irrigation: systematic review and meta-analysis. Am J Rhinol Allergy. 2018; 32(4): 269-79.

25. Jadczak M. Miejsce preparatów umożliwiających płukanie jam nosa w praktyce laryngologicznej. Pol Przegl Otorynolaryngol. 2013; 2: 226-9.

26. Liu L, Pan M, Li Y et al. Efficacy of nasal irrigation with hypertonic saline on chronic rhinosinusitis: systematic review and meta-analysis. Braz J Otorhinolaryngol. 2020; 16: S1808-8694.

27. Nimsakul S, Ruxrungtham S, Chusakul S et al. Does Heating up Saline for Nasal Irrigation Improve Mucociliary Function in Chronic Rhinosinusitis? Am J Rhinol Allergy. 2018; 32(2): 106-11.

28. Wills $P$, Greenstone M. Inhaled hyperosmolar agents for bronchiectasis. Cochrane Database Syst Rev. 2002; 1: CD002996.

29. Elkins MR, Robinson M, Rose BR et al. National Hypertonic Saline in Cystic Fibrosis (NHSCF) Study Group. A controlled trial of long-term inhaled hypertonic saline in patients with cystic fibrosis. N Engl J Med. 2006; 354: 229-40.

30. Jones AP, Wallis CE. Recombinant human deoxyribonuclease for cystic fibrosis. Cochrane Database Syst Rev. 2003; 3: $C D 001127$

31. Lin HL, Chiu LH, Wan GW et al. Hypertonic saline enhances the efficacy of aerosolized gentamicin against Pseudomonas aeruginosa. Sci Rep. 2020; 10: 4325.

32. Wark P, McDonald VM. Nebulised hypertonic saline for cystic fibrosis. Cochrane Database Syst Rev. 2018; 9(9): CD001506.

33. Mogayzel PJ, Naureckas ET, Robinson KA et al. Cystic fibrosis pulmonary guidelines. Am J Respir Crit Care Med. 2013; 187: 680-9.

34. Castellani C, Duff AJA, Bell SC et al. ECFS best practice guidelines: the 2018 revision. J Cystic Fibrosis. 2018; 17: $153-78$

35. Sands D, Walicka-Serzysko K, Doniec Z et al. ReKOMendacje Postepowania w MukowiScydozie (cystic fibrosis - CF) dla lekarzy POZ - KOMPAS CF. Ped Pol. 2017; 92: 431-45.

36. Nicolson $\mathrm{CH}$, Stirling RG, Borg BM et al. The long term effect of inhaled hypertonic saline 6\% in non-cystic fibrosis bronchiectasis. Respir Med. 2012; 106: 661-7.

37. Benjamin J, Tarrant BJ, Le Maitre C et al. Mucoactive agents for chronic, non-cystic fibrosis lung disease: A systematic review and meta-analysis. Respirology. 2017; 22: 1084-92.

38. Pasteur MC, Bilton D, Hill AT. On behalf of the British Thoracic Society Bronchiectasis (non-CF) Guideline Group. British Thoracic Society guideline for non-CF bronchiectasis. Thorax. 2010; 65: 1-58.
39. Máiz L, Girón RM, Prats E et al. Addition of hyaluronic acid improves tolerance to 7\% hypertonic saline solution in bronchiectasis patients. Ther Adv Respir Dis. 2018; 12: 1753466618787385.

40. Wabnitz DA, Wormald PJ. A blind, randomized, controlled study on the effect of buffered 0.9 and $3 \%$ sodium chloride intranasal sprays on ciliary beat frequency. Laryngoscope. 2005; 115: 803-5.

41. Sood N, Bennett WD, Zeman K et al. Increasing concentration of inhaled saline with or without amiloride: effect on mucociliary clearence in normal subjects. Am J Respir Crit Care Med. 2003; 167: 158-63.

42. Zhang L, Mendoza-Sassi RA, Wainwright $C$ et al. Nebulized hypertonic saline solution for acute bronchiolitis in infants. Cochrane Database Syst Rev. 2008; 4: CD006458.

43. Ralston SL, Lieberthal AS, Meissner HC et al. Clinical practice guideline: the diagnosis, management, and prevention of bronchiolitis. American Academy of Pediatrics. Pediatrics. 2014; 134(5): e1474-e1502.

44. Hryniewicz W, Albrecht P, Radzikowski A. Rekomendacje postępowania w pozaszpitalnych zakażeniach układu oddechowego. Narodowy Instytut Leków, Warszawa 2016.

45. Chen YJ, Lee WL, Wang CM et al. Nebulized hypertonic saline treatment reduces both rate and duration of hospitalization for acute bronchiolitis in infants: an updated meta-analysis. Pediatr Neonatol. 2014; 55(6): 431-8.

46. Zhang L, Mendoza-Sassi RA, Klassen TP et al. Nebulized hypertonic saline for acute bronchiolitis: a systematic review. Pediatrics. 2015; 136(4): 687-701

47. Zhang L, Mendoza-Sassi RA, Wainwright $C$ et al. Nebulised hypertonic saline solution for acute bronchiolitis in infants. Cochrane Database Syst Rev. 2017; 12(12): CD006458.

48. Zhang L, Gunther CB, Franco OS et al. Impact of hypertonic saline on hospitalization rate in infants with acute bronchiolitis: a meta-analysis. Pediatr Pulmonol. 2018; 53(8): 1089-95.

49. Harrison W, Angoulvant F, House $S$ et al. Hypertonic saline in bronchiolitis and type I error: a trial sequential analysis. Pediatrics. 2018; 142(3): e20181144.

50. Kirolos A, Manti $S$, Blacow R et al. A systematic review of clinical practice guidelines for the diagnosis and management of bronchiolitis. J Infect Dis. 2019; jiz240.

51. Hart A, Sugumar K, Milan SJ et al. Inhaled hyperosmolar agents for bronchiectasis. Cochrane Database Syst Rev. 2014; 5: CD002996.

52. Paff T, Daniels JM, Weersink EJ et al. A randomised controlled trial on the effect of inhaled hypertonic saline on quality of life in primary ciliary dyskinesia. Eur Respir J. 2017; 49: 1601770.

53. Valderramas SR, Atallah AN. Effectiveness and safety of hypertonic saline inhalation combined with exercise training in patients with chronic obstructive pulmonary disease: a randomized trial. Respir Care. 2009; 54: 327-33. 
54. Taube Ch, Holz O, Mücke Met al. Airway response to inhaled hypertonic saline in patients with moderate to severe chronic obstructive pulmonary disease. Am J Respir Crit Care Med. 2001; 164: 1810-5.

55. https://goldcopd.org/wp-content/uploads/2019/12/GOLD2020-FINAL-ver1.2-03Dec19_WMV.pdf(Access: 30.07.2020).

ORCID

A. Emeryk - ID - http://orcid.org/0000-0003-1853-8696

J. Emeryk-Maksymiuk - ID - http://orcid.org/0000-0003-2709-0424

K. Janeczek - ID - http://orcid.org/0000-0002-8163-873X

A. Jędrzejewski - ID - http://orcid.org/0000-0002-7965-2014

Wkład autorów/Authors' contributions:

A. Emeryk: finalne przygotowania manuskryptu; J. Emeryk-Maksymiuk: opracowanie fragmentu dotyczacego rozstrzeni oskrzeli i mukowiscydozy; K. Janeczek: opracowanie fragmentu zapalenia oskrzelików; A. Jędrzejewski: opracowanie fragmentu dotyczącego przeziębienia i ANN
Konflikt interesów/Conflict of interests:

Nie występuje.

Finansowanie/Financial support:

Nie występuje.

Etyka/Ethics:

Treści przedstawione w artykule są zgodne z zasadami Deklaracji Helsińskiej, dyrektywami

EU oraz ujednoliconymi wymaganiami dla czasopism biomedycznych.

Copyright: (C) Medical Education sp. z 0.0. This is an Open Access article distributed under the terms of the Attribution-NonCommercial 4.0 International (CC BY-NC 4.0). License (https://creativecommons.org/licenses/by-nc/4.0/), allowing third parties to copy and redistribute the material in any medium or format and to remix, transform, and build upon the material, provided the original work is properly cited and states its license.

Adres do korespondencji

prof. dr hab. n. med. Andrzej Emeryk

Klinika Chorób Płuc i Reumatologii Dziecięcej,

Uniwersytet Medyczny w Lublinie

20-093 Lublin, ul. A. Gębali 6

e-mail: emerykandrzej@gmail.com

(c) Medical Education. For private and non-commercial use only. Downloaded from https://www.journalsmededu.pl/index.php/alergoprofil: 26.04.2023; 16:26,11 